Economics Development Analysis Journal

\title{
Determinan Kualitas Pembangunan Manusia di Kabupaten/Kota Provinsi Jawa Tengah
}

Agung Yudhi Pramono ${ }^{1 凶}$, Etty Soesilowati ${ }^{2}$

Jurusan Ekonomi Pembangunan, Fakultas Ekonomi, Universitas Negeri Semarang

\begin{tabular}{|c|c|}
\hline Info Artikel & Abstrak \\
\hline $\begin{array}{l}\text { Keywords: } \\
\text { HDI, Local Government } \\
\text { Expenditure in Educational } \\
\text { Sector, Local Government } \\
\text { Expenditure in Health } \\
\text { Sector, Dependency Ratio, } \\
\text { Per Capita Income. }\end{array}$ & $\begin{array}{l}\text { Penelitian ini bertujuan untuk menganalisis seberapa besar pengaruh pengeluaran pemerintah } \\
\text { daerah sektor pendidikan, pengeluaran pemerintah daerah sektor kesehatan, rasio ketergantungan } \\
\text { penduduk dan pendapatan perkapita terhadap pembangunan manusia yang diukur dengan IPM. } \\
\text { Populasi penelitian terdiri dari } 35 \text { Kabupaten/Kota di Provinsi Jawa Tengah, menggunakan data } \\
\text { sekunder dari Badan Pusat Statistik Provinsi Jawa Tengah dan Biro Keuangan Sekretaris Daerah } \\
\text { Provinsi Jawa Tengah dalam periode } 2009 \text { sampai } 2013 \text {. Variabel penelitian ini indeks } \\
\text { pembangunan manusia, pengeluran pemerintah daerah sektor pendidikan, pengeluaran } \\
\text { pemerintah daerah sektor kesehatan, rasio ketergantungan penduduk, dan pendapatan perkapita } \\
\text { Dalam penelitian ini, digunakan metode penelitian kuantitatif dengan menggunakan analisis } \\
\text { regresi data panel model efek tetap (FEM) dengan metode Generalized Least Square (GLS). Hasi } \\
\text { penelitian ini dapat diketahui bahwa pengeluaran pemerintah daerah sektor pendidikan } \\
\text { berpengaruh positif dan signifikan terhadap IPM, pengeluaran pemerintah daerah sektor kesehatan } \\
\text { berpengaruh positif dan signifikan terhadap IPM, rasio ketergantungan penduduk berpengaruh } \\
\text { negatif dan signifikan terhadap IPM, sementara pendapatan perkapita tidak berpengaruh secara } \\
\text { signifikan terhadap IPM. }\end{array}$ \\
\hline
\end{tabular}

\begin{abstract}
This research has purpose to analyze how much influence of the local government expenditure in educational sector, local government expenditure in health sector, dependency ratio, and per capita income of a human development measured by HDI. the population of this research consists of 35 regionals in Central Java and region bureau money secretary of Central Java province among 2009 and 2013 period. the variables used in this research are HDI, local government expenditure in educational sector, local government expenditure in health sector, dependency ratio, and per capita income. in this research, quantitative and regression analysis of Fixed Effect Model is used as well as Generalized Least Square method (GLS). The results of this research are the outcome of regional government in educational and health sector influence significance and positively to the $H D I$, dependency ratio significance and negatively influence to the HDI, while per capita income does not influence significance to the HDI.
\end{abstract}

(C) 2016 Universitas Negeri Semarang

\footnotetext{
Alamat korespondensi:

Ruang Jurnal,Gedung L FE UNNES Sekaran Gunungpati

Semarang 50229, Indonesia

E-mail: agung.yipi@gmail.com
} ISSN 2252-6765 


\section{PENDAHULUAN}

Otonomi daerah di Indonesia memasuki babak baru, dengan ditetapkannya UU Nomor 23 Tahun 2014 tentang Pemerintahan Daerah. Dijelaskan dalam UU No 23 Tahun 2014 bahwa pemberian otonomi yang seluas-luasnya kepada daerah diarahkan untuk mempercepat terwujudnya kesejahteraan masyarakat melalui peningkatan pelayanan, pemberdayaan, dan peran serta masyarakat. Kesejahteraan masyarakat sendiri dapat dilihat dari kualitas pembangunan manusia yang ada di daerah tersebut. Menurut (Mariano et al., 2015) pembangunan manusia termasuk memperluas kesejahteraan bagi semua orang dan meningkatkan kemungkinan pilihan individu.Kualitas pembangunan manusia pembangunan manusia dapat dilihat dari Human Development Index (HDI) atau yang lebih dikenal sebagai Indeks Pembanguan Manusia yang dikenalkan pertama kali oleh United Nations Development Programme (UNDP) pada tahun 1990.

Menurut (Widodo, dkk.,2011) Pembangunan manusia merupakan salah satu indikator bagi kemajuan suatu negara. Suatu negara dikatakan maju bukan saja dihitung dari pendapatan domestik bruto saja tetapi juga mencakup aspek harapan hidup serta pendidikan masyarakatnya. Hal ini bisa artikan bahwa pembangunan manusia merupakan salah satu indikator bagi suatu daerah dalam pembangunan, dimana pembangunan suatu daerah tidak bisa dikatakan berhasil apabila hanya melihat dari besarnya pendapatan domestik regional bruto saja tanpa meningkatkan pembangunan manusianya.

Berdasarkan data dari BPS (2014) untuk wilayah provinsi di Indonesia perkembangan pembangunan manusia beragam. Pada tahun 2013 wilayah provinsi di Indonesia angka IPM tertinggi adalah Provinsi DKI Jakarta dengan angka IPM sebesar 78,59. Selanjutnya untuk wilayah Provinsi lain di Indonesia pada tahun 2013 angka Indeks Pembangunan Manusianya beragam. Secara keselurahan dari tahun 2012 sampai tahun 2013 nilai IPM Provinsi di Indonesia mengalami peningkatan, walaupun peningkatannya tidak terlalu signifikan. Pencapaian pembangunan manusia di Pulau Jawa hanya Provinsi DKI Jakarta dan D.I Yogyakarta yang mampu mencapai kedalam peringkat lima besar di Indonesia, dimana Provinsi DKI Jakarta dan D.I Yogyakarta menempati posisi satu dan dua dalam peringkat IPM secara nasional. Sementara untuk wilayah lainnya di Pulau Jawa khususnya Jawa Tengah posisinya justru tergeser oleh Provinsi diluar Pulau Jawa yaitu Bali, yang tergeser ke peringkat 16 secara nasional.

Pencapaian pembangunan manusia antar daerah tentunya tidak sama, bergantung pada komitmen pemerintah daerah dalam penyelenggaraan pembangunan. Perjalanan Jawa Tengah dalam mewujudkan pembangunan manusia yang ideal tampaknya masih sangat panjang mengingat belum satu pun kabupaten/kota yang masuk dalam kategori capaiam IPM tinggi. Bahkan jika disandingkan dengan 497 kabupaten/kota di Indonesia, belum satu pun kabupaten/kota di Jawa Tengah yang masuk dalam 10 besar IPM tertinggi di Indonesia (BPS, 2012). Tabel 1 dibawah ini megenai data 10 besar indeks pembangunan manusia tertinggi kabupaten/kota di Indonesia tahun 2009-2013.

Sementara bila dilihat dari nilai rata-rata IPM selama tahun 2009 sampai dengan tahun 2013 nilai rata-rata IPM kabupaten/kota di Jawa Tengah memiliki perkembangan IPM yang positif, yang ditunjukkan dengan meningkatnya IPM masing-masing kabupaten/kota selama tahun 2009 sampai tahun 2013 seiring dengan meningkatnya IPM Provinsi Jawa Tengah. Jika

Dilihat dari rata-rata IPM Provinsi Jawa Tengah selama tahun 2009 sampai tahun 2013 sebesar 72,988, maka terdapat 18 kabupaten di Jawa Tengah pada tahun 2013 yang memiliki nilai rata-rata IPM dibawah nilai rata-rata IPM Provinsi. Berikut gambar pada grafik 1 dibawah ini mengenai nilai rata-rata IPM kabupaten/kota di Provinsi Jawa Tengah. 
Tabel 1. Sepuluh Kabupaten/Kota IPM Tertinggi di Indonesia Tahun 2009-2013

\begin{tabular}{cccccc}
\hline \multirow{2}{*}{ Kabupaten/Kota } & \multicolumn{5}{c}{ Indeks Pembangunan Manusia (IPM) } \\
\cline { 2 - 6 } & $\mathbf{2 0 0 9}$ & $\mathbf{2 0 1 0}$ & $\mathbf{2 0 1 1}$ & $\mathbf{2 0 1 2}$ & $\mathbf{2 0 1 3}$ \\
\hline Kota Yogyakarta & 79,29 & 79,52 & 79,89 & 80,24 & 80,51 \\
Kota Jakarta Selatan & 79,26 & 79,47 & 79,82 & 80,17 & 80,47 \\
Kota Makasar & 78,24 & 78,79 & 79,11 & 79,49 & 80,17 \\
Kota Depok & 78,77 & 79,09 & 79,36 & 79,71 & 80,14 \\
Kota Jakarta Timur & 78,74 & 78,95 & 79,31 & 79,80 & 80,07 \\
Kab. Sleman & 77,70 & 78,20 & 78,79 & 79,39 & 79,97 \\
Kota Balikpapan & 77,86 & 78,33 & 78,85 & 79,38 & 79,87 \\
Kota Jakarta Barat & 78,63 & 78,84 & 79,09 & 79,43 & 79,69 \\
Kota Ambon & 78,25 & 78,56 & 78,97 & 79,41 & 79,58 \\
Kota Palangka Raya & 78,02 & 78,30 & 78,78 & 79,30 & 79,52 \\
\hline
\end{tabular}

Sumber: BPS, 2010-2013

Grafik 1. Nilai rata-rata IPM Kabupaten/Kota Provinsi Jawa Tengah Tahun 2009-2013

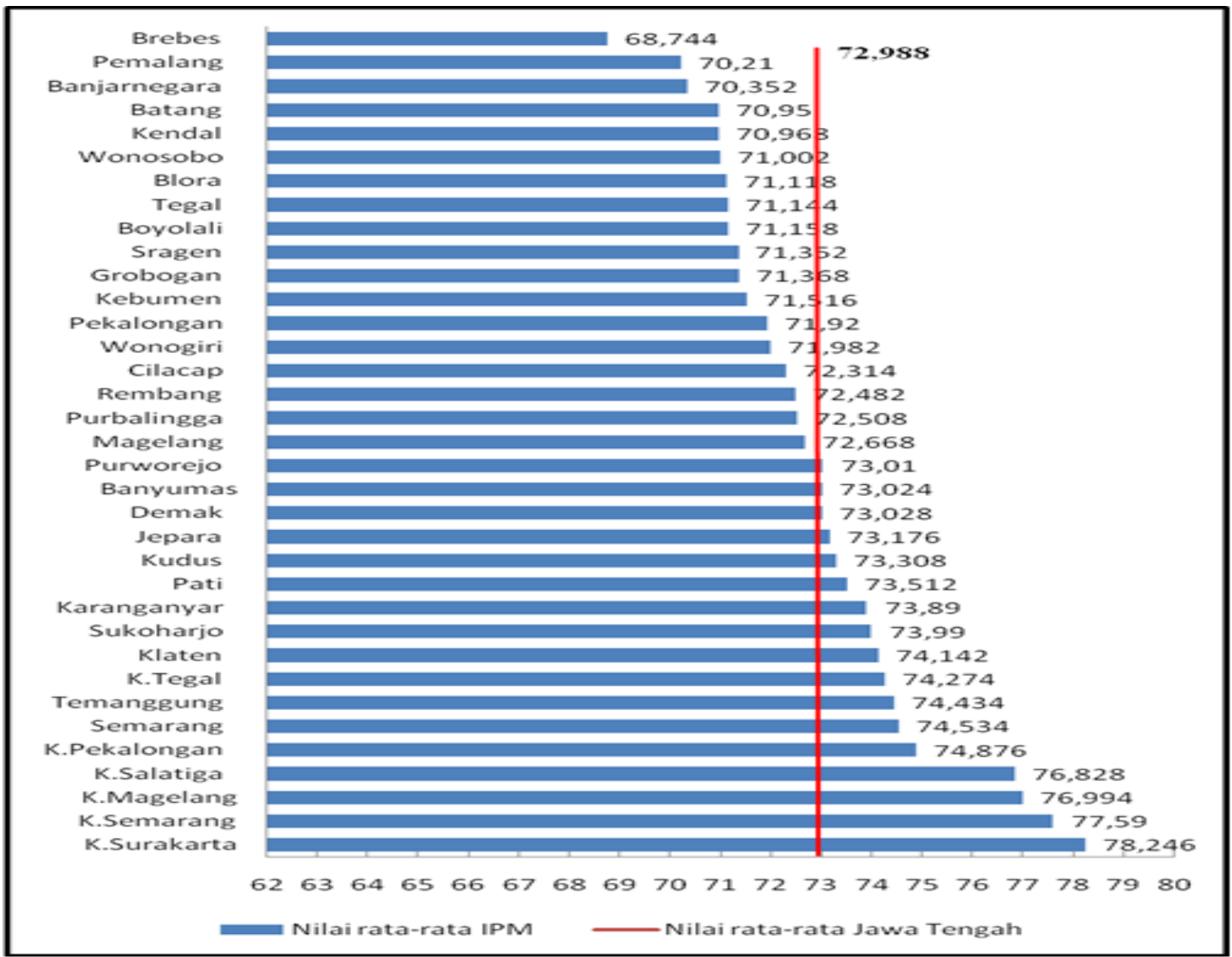

Sumber: BPS 2009-2013, data diolah

Meningkatnya kegiatan pemerintah daerah setelah berlakunya otonomi daerah dalam rangka menjalankan peran yang ada, maka dibutuhkan suatu pengeluaran yang lebih besar guna menjalankan kegiatan pemerintah yang berkaitan dengan peran pemerintah. Pengeluaran pemerintah di suatu daerah mencerminkan kebijakan yang diambil oleh daerah tersebut. Lebih spesifiknya pemerintah daerah harus bisa mengalokasikan belanja daerah melalui pengeluaran pembangunan di sektor-sektor pendukung untuk meningkatkan IPM misalnya yang tercermin pada realisasi 
belanja daerah untuk bidang pendidikan dan kesehatan (Artaningtyas, dkk, 2011).

Pendidikan dan kesehatan merupakan tujuan pembangunan yang mendasar, terlepas dari hal-hal yang lain, kedua hal itu merupakan hal yang penting. Gupta et. Al. (1998) dalam (Prasetyo \& Zuhdi, 2013) menyebutkan bahwa pengeluaran pemerintah di sektor kesehatan dan pendidikan bisa membawa efek positif pada modal manusia yang pada akhirnya, meningkatkan pertumbuhan ekonomi sekaligus mempromosikan ekuitas dan mengurangi kemiskinan. Kesehatan merupakan inti dari kesejahteraan, dan pendidikan adalah hal pokok untuk menggapai kehidupan yang memuaskan dan berharga, keduanya adalah hal yang fundamental untuk membentuk kapabilitas manusia yang lebih luas yang berada pada inti makna pembangunan (Todaro, 2003).

Tabel 2. Rata-rata Pengeluaran Pemerintah Sektor Pendidikan di Kabupaten/Kota Provinsi Jawa Tengah Tahun 2009-2013

\begin{tabular}{cccc}
\hline \multirow{2}{*}{ Tahun } & \multirow{2}{*}{$\begin{array}{c}\text { Rata-rata } \\
\text { Pengeluaran }\end{array}$} & Rata-rata \\
\cline { 3 - 4 } & & 348.256 .395 .783 & 206.514 .040 .142 \\
\hline $\mathbf{2 0 0 9}$ & 323.957 .706 .244 & 388.724 .895 .735 & 221.442 .862 .195 \\
$\mathbf{2 0 1 0}$ & 360.047 .975 .700 & 553.384 .796 .931 & 294.042 .788 .167 \\
$\mathbf{2 0 1 1}$ & 508.926 .166 .857 & 618.895 .787 .887 & 352.705 .104 .950 \\
$\mathbf{2 0 1 2}$ & 573.263 .099 .383 & 686.190 .718 .139 & 416.868 .240 .550 \\
$\mathbf{2 0 1 3}$ & 640.021 .150 .553 & & Kota \\
\hline
\end{tabular}

Sumber : Biro Keuangan Sekretaris Daerah Provinsi Jawa Tengah 2009-2013,data diolah

Berdasarkan Tabel 2 menunjukkan ratarata alokasi pengeluaran pemerintah untuk sektor pendidikan mengalami perkembangan yang positif, dimana rata-rata pengeluaran pemerintah untuk sektor pendidikan selalu meningkat selama tahun 2009 sampai tahun 2013. Perkembangan rata-rata alokasi pengeluaran sektor pendidikan wilayah kabupaten dan kota di Jawa Tengah juga menunjukkan hubungan yang positif dengan total pengeluaran pemerintah sektor pendidikan. Pada tahun 2009 rata-rata pengeluaran pemerintah di seluruh kabupaten sebesar Rp 348.256.395.783 sampai tahun 2013 meningkat menjadi Rp 686.190.718.139. Sedangkan pada tahun 2009 rata-rata pengeluaran pemerintah untuk sektor pendidikan seluruh kota sebesar Rp 206.514.040.142 dan sampai tahun 2013 meningkat menjadi Rp 416.868.240.550. Secara umum dapat diketahui bahwa pada tahun 2009 sampai 2013, rata-rata alokasi pengeluaran pemerintah sektor pendidikan di kota berada dibawah rata-rata alokasi pengeluaran pemerintah kabupaten di Provinsi Jawa Tengah. Hal ini menunjukkan bahwa dalam menunjang pendidikan di wilayah kabupaten, pemerintah membutuhkan alokasi biaya yang lebih banyak daripada di wilayah kota. Rata-rata alokasi pengeluaran pemerintah sektor pendidikan di seluruh kabupaten di Provinsi Jawa Tengah yang lebih tinggi daripada rata-rata alokasi pengeluaran sektor pendidikan di wilayah kota di Provinsi Jawa Tengah, seharusnya dapat pula meningkatkan IPM di wilayah kabupaten Provinsi Jawa Tengah. 
Tabel 3. Rata-rata Pengeluaran Pemerintah Sektor Kesehatan Kabupaten/Kota di Provinsi Jawa Tengah Tahun 2009-2013

\begin{tabular}{cccc}
\hline \multirow{2}{*}{ Tahun } & \multirow{2}{*}{$\begin{array}{c}\text { Rata-rata } \\
\text { Pengeluaran }\end{array}$} & \multicolumn{2}{c}{ Rata-rata } \\
\cline { 3 - 4 } & & Kabupaten & Kota \\
\hline $\mathbf{2 0 0 9}$ & 76.243 .829 .155 & 79.848 .136 .863 & 58.823 .008 .568 \\
$\mathbf{2 0 1 0}$ & 90.877 .674 .179 & 94.093 .739 .877 & 75.333 .356 .637 \\
$\mathbf{2 0 1 1}$ & 107.948 .584 .400 & 110.314 .352 .069 & 96.514 .040 .667 \\
$\mathbf{2 0 1 2}$ & 129.458 .153 .554 & 132.708 .603 .351 & 113.747 .646 .200 \\
$\mathbf{2 0 1 3}$ & 150.995 .588 .820 & 154.208 .645 .540 & 135.465 .814 .673 \\
\hline
\end{tabular}

Sumber: Biro Keuangan Sekretaris Daerah Jawa Tengah 2009-2013, data diolah

Berdasarkan Tabel 3 menunjukkan ratarata alokasi pengeluaran pemerintah untuk sektor kesehatan mengalami perkembangan yang positif, dimana rata-rata pengeluaran pemerintah untuk sektor kesehatan selalu meningkat selama tahuan 2009 sampai tahun 2013. Perkembangan rata-rata alokasi pengeluaran sektor kesehatan wilayah kabupaten dan kota di Jawa Tengah juga menunjukkan hubungan yang positif dengan total pengeluaran pemerintah sektor pendidikan. Pada tahun 2009 rata-rata pengeluaran pemerintah di seluruh kabupaten sebesar $\mathrm{Rp}$ 79.848.136.863 sampai tahun 2013 meningkat menjadi Rp 154.208.645.540. Sedangkan pada tahun 2009 rata-rata pengeluaran pemerintah untuk sektor kesehatan seluruh kota sebesar Rp 58.823.008.568 dan sampai tahun 2013 meningkat menjadi Rp 135.465.814.673.

Secara umum dapat diketahui bahwa pada tahun 2009 sampai 2013, rata-rata alokasi pengeluaran pemerintah sektor kesehatan di kota berada dibawah rata-rata alokasi pengeluaran pemerintah kabupaten di Provinsi Jawa Tengah. Hal ini menunjukkan bahwa dalam menunjang kesehatan di wilayah kabupaten, pemerintah membutuhkan alokasi biaya yang lebih banyak daripada di wilayah kota. Rata-rata alokasi pengeluaran pemerintah sektor kesehatan di seluruh kabupaten di Provinsi Jawa Tengah yang lebih tinggi daripada rata-rata alokasi pengeluaran sektor kesehatan di wilayah kota di Provinsi Jawa Tengah, seharusnya dapat pula meningkatkan IPM di wilayah kabupaten Provinsi Jawa Tengah.

Dalam penelitian (Hafner \& MayerFoulkes, 2013) menjelaskan bahwa negaranegara berkembang mengalami kesulitan yang signifikan dalam meningkatkan modal manusianya. Selain dari sisi anggaran, kondisi sosial ekonomi masyarakat juga dapat mempengaruhi kualitas pembangunan manusia, yaitu apabila jumlah penduduk disuatu daerah lebih banyak penduduk yang berusia kurang produktif daripada penduduk yang berusia produktif. Banyaknya jumlah penduduk pada kelompok usia produktif dibandingkan kelompok usia non-produktif dapat memberikan manfaat bagi pembangunan nasional terutama pada sektor ekonomi. Akan tetapi untuk memanfaatkan kondisi tersebut, kualitas SDM harus ditingkatkan secara maksimal antara lain melalui pendidikan, pelayanan kesehatan dan penyediaan lapangan pekerjaan (BKKBN, 2013). Hal ini dikarenakan penduduk yang produktif harus menanggung beban lebih banyak penduduk yang kurang produktif. Penduduk produktif yang dimaksud disini adalah mereka yang berumur 15 hingga 64 tahun, dan penduduk yang kurang produktif disini mereka yang umurnya kurang dari 15 tahun dan lebih dari 65 tahun. Kondisi dan situasi seperti ini tentunya dapat menghambat pembangunan kualitas pembangunan manusia di daerah. 


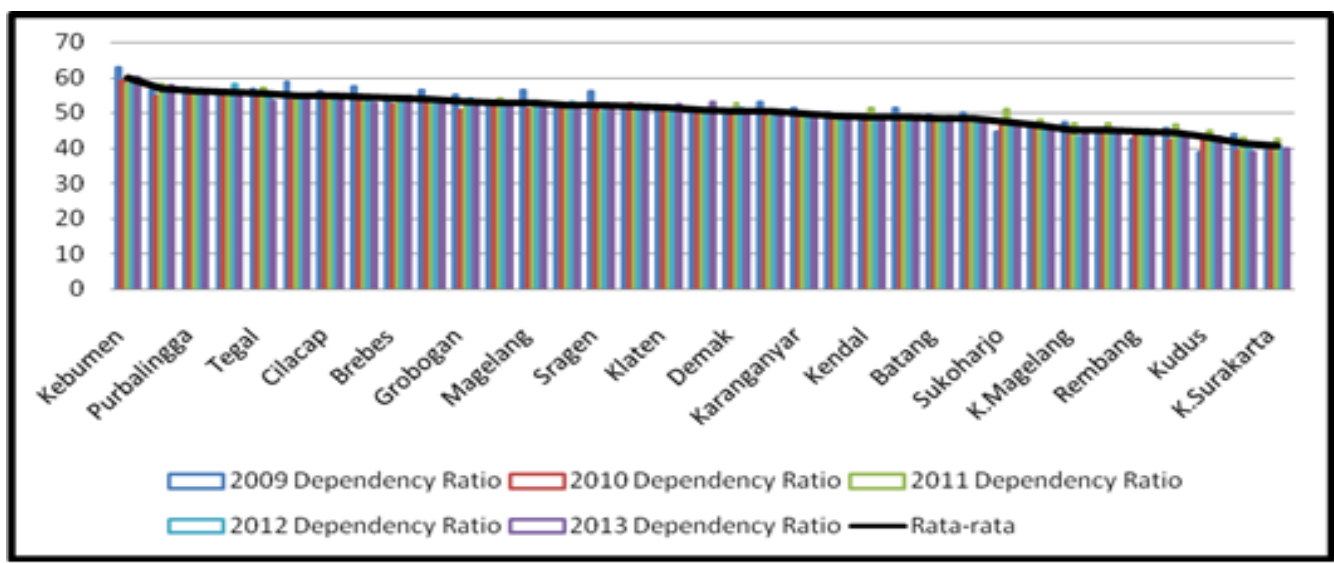

Grafik 2. Perkembangan dan Nilai Rata-rata Dependency Ratio Kab/Kota di Provinsi Jawa Tengah Tahun 2009-2013

Sumber : Indikator kesejahteraan rakyat Jawa Tengah,2009-2013

Berdasarkan grafik 2 menunjukkan bahwa rasio ketergantungan penduduk kabupaten/kota di Jawa Tengah memiliki perkembangan yang positif dan beragam, dimana setiap tahunnya nilai rasio ketergantungan penduduk diwilayah kabupaten/kota mengalami penurunan, artinya beban ketergantungan dari penduduk turun. Menurut nilai rata-rata dependency ratio diatas nilai rasio ketergantungan penduduk wilayah Kabupaten masih tinggi dibandingkan dengan wilayah Kota, hal ini menunjukkan bahwa beban penduduk usia produktif diwilayah Kabupaten masih tinggi dibandingkan dengan wilayah Kota.

Kondisi sosial ekonomi masyarakat lainnya yang dapat mempengaruhi kualitas pembangunan manusia selain yakni dari segi pendapatan masyarakat. Menurut Sasana (2012) Jika seseorang memiliki pendapatan yang lebih besar maka orang tersebut dapat memenuhi kebutuhan hidupnya selain hanya untuk memenuhi kebutuhan primernya seperti sandang, pangan, dan papan, tetapi juga dapat memenuhi kebutuhan lain seperti kesehatan dan pendidikan. Pendapatan yang dimaksud adalah pendapatan perkapita yaitu besarnya pendapatan rata-rata di suatu daerah dibandingkan dengan jumlah penduduknya. Pendapatan perkapita juga mencerminkan tingkat daya beli penduduk di suatu daerah, dengan semakin besarnya pendapatan maka semakin besar juga pengeluarannya.

\section{METODE PENELITIAN}

Jenis penelitian ini adalah penelitian kuantitatif yang bersumber dari data sekunder. Data yang digunakan dalam penelitian ini merupakan data sekunder yang bersumber pada laporan Badan Pusat Statistik (BPS) tahun 2009 sampai dengan tahun 2013, data yang diteliti meliputi data rasio ketergantungan penduduk, pendapatan perkapita, dan Indeks Pembangunan Manusia (IPM). Sumber data juga berasal dari Sekretaris Daerah Biro Keuangan Provinsi Jawa Tengah tahun 2009 sampai tahun 2013, data yang diteliti meliputi alokasi pengeluaran pemerintah daerah di sektor pendidikan dan kesehatan. Jenis data yang digunakan adalah data panel yaitu gabungan data time series dan cross section. Data time series periode tahun 2009-2013 sedangkan data cross section adalah 35 kabupaten/kota di Provinsi Jawa Tengah.

Penelitian ini menggunakan dua jenis variabel yaitu variabel dependen dan variabel independen. Variabel dependen dalam penelitian ini adalah kualitas pembangunan manusia yang diukur dengan IPM, sedangkan variabel independennya adalah pengeluaran pemerintah daerah sektor pendidikan, pengeluaran pemerintah daerah sektor 
kesehatan, rasio ketergantungan penduduk dan pendapatan perkapita penduduk.

Dalam penelitian ini, sesuai dengan bentuk pendekatan penelitian kuantitatif maka metode pengumpulan data yang digunakan adalah metode dokumentasi. Dalam penelitian ini menggunakan metode dokumentasi yang bersumber dari Badan Pusat Statistik (BPS), Biro Keuangan Sekretaris Daerah Provinsi Jawa Tengah dengan mengambil seluruh populasi yaitu sebanyak 35 kabupaten/kota di Provinsi Jawa Tengah.

Penelitian ini menggunakan metode penelitian kuantitatif dengan menggunakan data panel. Menurut Gujarati (2013) data panel (pooled data) atau yang disebut juga data longitudinal merupakan gabungan antara data cross section dan data time series. Data cross section adalah data yang dikumpulkan dalam satu waktu terhadap banyak individu, sedangkan data time series merupakan data yang dikumpulkan dari waktu ke waktu terhadap suatu individu. Menurut Widarjono (2009) untuk mengetimasi model regresi dengan data panel menggunakan tiga pendekatan yaitu pendekatan common effect, fixed effect, pada estimasi pendekatan fixed effect dilakukan dengan pembobot (cross section weight) atau metode Generalized Least Square (GLS). Tujuan dilakukan GLS untuk mengatasi masalah heterokedastisitas antar unit cross section., dan random effect.

\section{Spesifikasi Model Regresi}

Secara ekonometrika pengaruh pengeluaran pemerintah daerah sektor pendidikan (logPNGPD), pengeluaran pemerintah daerah sektor kesehatan (logPNGKES), rasio ketergantungan penduduk (DR), dan pendapatan perkapita (logPENKAP) terhadap indeks pembangunan manusia di Kabupaten/Kota Provinsi Jawa Tengah dapat dianalisis dengan menggunakan persamaan sebagai berikut ini:

$\mathrm{IPM}_{\mathrm{it}}=\beta_{0}+\beta_{1} \operatorname{LogPNGPD}_{\mathrm{it}}+\beta_{2} \operatorname{LogPNGKES}_{\mathrm{it}}$ $+\beta_{3} \mathrm{DR}_{\text {it }}+\beta_{4} \log \mathrm{PENKAP}_{\text {it }}+\mu$ it.

Keterangan :

\begin{tabular}{|c|c|}
\hline IPM & $=$ Indeks Pembangunan Manusia \\
\hline LogPNGPD & $\begin{aligned}= & \text { Pengeluaran pemerintah daerah } \\
& \text { sektor pendidikan (rupiah) }\end{aligned}$ \\
\hline LogPNGKES & $\begin{aligned}= & \text { Pengeluaran pemerintah daerah } \\
& \text { sektor kesehatan (rupiah) }\end{aligned}$ \\
\hline DR & $=$ Rasio Ketergantungan $(\%)$ \\
\hline LogPENKAP & $=$ Pendapatan Perkapita (rupiah) \\
\hline$\beta$ & $=$ Koefisien regresi \\
\hline $\mathrm{i}$ & $\begin{aligned}= & \text { Kabupaten } / \text { kota } \mathrm{i}(\mathrm{i}=1,2,3 \ldots .35 ; \mathrm{t} \\
& \text { tahun ke-t }(2009-2013)\end{aligned}$ \\
\hline$\mu \mathrm{it}$ & $\begin{array}{l}=\text { Nilai residual } \\
\text { pengganggu) yang } \\
\text { model. }\end{array}$ \\
\hline
\end{tabular}

\section{HASIL DAN PEMBAHASAN}

\section{Uji Spesifikasi Model}

Tahap pertama yaitu dengan uji chow test untuk menentukan model terbaik antara common effect dan fixed effect. Berdasarkan hasil pengujian chow test diketahui bahwa cross section $F$ sebesar 345.570536 dengan $p$-value 0.0000 signifikan pada $\alpha=5 \%$. Karena probalititas cross-section $F$ signifikan pada $\alpha=5 \%$, dengan demikian pengambilan keputusan model terbaik yang digunakan adalah fixed effect model. Pada tahap kedua dilakukan dengan uji hausman test untuk menentukan model terbaik antara fixed effect dan random effect. Berdasarkan hasil hausman test dapat diketahui bahwa cross-section random sebesar 55.753426 dengan p-value cross-section random sebesar 0.0000 signifikan pada $\alpha=5 \%$, dengan demikian pengambilan keputusan model terbaik yang digunakan adalah fixed effect model.

Model regresi terkait pengaruh variabel pengeluaran pemerintah daerah sektor pendidikan, pengeluaran pemerintah daerah sektor kesehatan, rasio ketergantungan penduduk dan pendapatan perkapita terhadap indeks pembangunan manusia menggunakan model terbaik yaitu fixed effect model dengan metode Generalized Least Square (GLS). Persamaan model FEM adalah sebagai berikut :

$\mathrm{IPM}_{\mathrm{it}}=\beta_{0}-\beta_{1} \log \mathrm{PNGPD}_{\mathrm{it}}+\beta_{2} \log \mathrm{PNGKES} \mathrm{S}_{\mathrm{it}}$ $+\beta_{3} \mathrm{DR}_{\mathrm{it}}+\beta_{4} \log \mathrm{PENKAP} \mathrm{it}_{\mathrm{it}}+\mu_{\mathrm{it}} \ldots \ldots \ldots \ldots \ldots$..... (2) 
$\mathrm{IPM}_{\mathrm{it}}=11.94345+1.233858 \log \mathrm{PNGPD}_{\mathrm{it}}+$ $1.097806 \log \mathrm{PNGKES}_{\text {it }}-0.021688 \mathrm{DR}_{\mathrm{it}}+$ $0.077064 \log \mathrm{PENKAP}_{\text {it }}+\mu_{\mathrm{it}}$

Std error (1.699401) (0.114553) (0.123106) (0.010081) (0.072457)

Prob (0.0000) (0.0000)

(0.0000) (0.0332) (0.2894).

Berdasarkan hasil estimasi menunjukkan bahwa pengeluaran pemerintah daerah sektor pendidikan berpengaruh posifitif dan signifikan pada taraf nyata 5 persen dengan koefisien sebesar 1,233858 dengan probabilitas ( $p$-value) sebesar 0,0000. Hal ini menunjukkan bahwa apabila pengeluaran pemerintah daerah sektor pendidikan meningkat $1 \%$ maka nilai IPM akan mengalami peningkatan sebesar 1,23 dengan asumsi ceteris paribus.

Sementara untuk pengeluaran pemerintah daerah sektor kesehatan berpengaruh positif dan signifikan pada taraf nyata 5 persen dengan koefisien sebesar 1,097806 dengan probabilitas (p-value) sebesar 0,0000. Hal ini menunjukkan bahwa apabila pengeluaran pemerintah daerah sektor kesehatan meningkat 1\% maka nilai IPM akan mengalami peningkatan sebesar 1,09 dengan asumsi ceteris paribus.

Sedangkan rasio ketergantungan penduduk berpengaruh negatif dan signifikan pada taraf nyata 5 persen dengan koefisien sebesar -0,021688 dengan probabilitas ( $p$-value) sebesar 0,0332. Hal ini menunjukkan bahwa apabila rasio ketergantingan penduduk mengalami penurunan 1\% maka nilai IPM akan mengalami peningkatan sebesar 0,02 dengan asumsi ceteris paribus, dan pendapatan perkapita berpengaruh positif dan tidak signifikan pada taraf nyata 5 persen dengan koefisien sebesar 0,077064 dengan probabilitas ( $p$-value) sebesar 0,2894. Hal tersebut berarti pendapatan perkapita belum sepenuhnya mempengaruhi nilai indeks pembangunan manusia di Kabupaten/Kota Provinsi Jawa Tengah.

\section{SIMPULAN}

Berdasarkan hasil penelitian dan pembahasan pengeluaran pemerintah daerah sektor pendidikan mempunyai pengaruh positif dan signifikan terhadap IPM di Kabupaten/Kota Provinsi Jawa Tengah. Pengeluaran pemerintah daerah sektor kesehatan mempunyai pengaruh positif dan signifikan terhadap IPM di Kabupaten/Kota Provinsi Jawa Tengah. Rasio ketergantungan penduduk mempunyai pengaruh negatif dan signifikan terhadap IPM di Kabupaten/Kota Provinsi Jawa Tengah. Pendapatan perkapita tidak berpengaruuh secara signifikan terhadap IPM di Kabupaten/Kota Provinsi Jawa Tengah.

Berdasarkan kesimpulan dari hasil penelitian dan pembahasan maka saran dalam penelitian ini adalah dalam meningkatkan IPM di Kabupaten/Kota Provinsi Jawa Tengah sebaiknya ada peningkatan pelayanan dasar dalam urusan pemerintahan wajib serta pemerataan progam pemerintah daerah Kabupaten/Kota dalam meningkatkan kualitas pendidikan seperti peningkatan kompetensi tenaga pendidik dan meningkatkan beasiswa pendidikan khususnya pada masyarakat miskin. Berdasarkan besarnya proporsi alokasi pengeluaran pemerintah daerah sektor kesehatan diharapkan pemerintah daerah Kabupaten/Kota memenuhi standar minimal proporsi yang ditetapkan oleh UU No.36 tahun 2009 yaitu sebesar 10\% dari total APBD. Sebaiknya diadakan evaluasi secara berkala dan meneruskan upaya pengendalian penduduk dengan diimbangi peningkatan kualitas sumberdaya penduduk usia kerja di Kabupaten/Kota Provinsi Jawa Tengah. Selain itu perlu adanya revitalisasi progam $\mathrm{KB}$ dengan penentuan sasaran yang jelas, khususnya bagi masyarakat yang rendah akan pendidikan.

\section{DAFTAR PUSTAKA}

Artaningtyas, Dwi., Wahyu, Akhmad Syari'udin, Dan Tri Maryani. 2011. Analisis Indeks Pembangunan Manusia di Provinsi Jawa Tengah. Buletin Ekonomi, Vol 9, No.1, April 2011: Hal 1-82

Badan Pusat Statistik. 2014. Indeks Pembangunan Manusia 2004-2014. BPS. Jawa Tengah. (Publikasi Online)

2013. Indikator Kesejahteraan Rakyat Jawa Tengah 2013. BPS. Jawa Tengah. 
Badan Pusat Statistik. 2013. Indeks Pembangunan Manusia 2013. Badan Pusat Statistik. JakartaIndonesia.

Biro Keuangan Sekretaris Daerah Provinsi Jawa Tengah. Alokasi Pengeluaran Pemerintah Daerah Sektor Pendidikan dan Kesehatan di Kabupaten/Kota Provinsi Jawa Tengah, Tahun 2009-2013

BKKBN. 2013. Pembangunan Kependudukan dan Keluarga Berencana Nasional. Provinsi Jawa Tengah,BKKBN. Jawa Tengah.

BPS Jawa Tengah. 2012. Analisis Kualitas Pembangunan Manusia. Jawa Tengah: BPS Jawa Tengah.

Gujarati, D.N. dan D.C. Porter. 2013. Dasar-Dasar Ekonometrika, Edisi 5 Buku 2. Jakarta: Salemba Empat

Habullah, Y., Fauzi, M., Fatimah, S., Yuniarti, T., \& Syarifudin, S. (2012). Analisis Arah Kebijakan Ekonomi Terhadap Sektor Pendidikan Dalam Peningkatan IPM. JEJAK: Jurnal Ekonomi Dan Kebijakan, 5(2).

Hafner, K.A. \& Mayer-Foulkes, , 2013. Fertility, economic growth, and human development causal determinants of the developed lifestyle. Journal of Macroeconomics.

Hidayat, A. (2016). Efektivitas Program Dana Bergulir Bagi Perkembangan Usaha Koperasi Di Kota Semarang. Economics Development Analysis Journal, 5(2).

Mariano, , Sobreiro, \& Rebelatto, D.A.d.N., 2015. Human Development and Data Envelopment. The International Journal of Management Science (OMEGA).

Mirza, D. (2015). Pengaruh Kemiskinan,

Pertumbuhan Ekonomi, Dan Belanja Modal Terhadap Ipm Jawa Tengah. JEJAK: Jurnal Ekonomi Dan Kebijakan, 4(2).

Prasetyo, \& Zuhdi, , 2013. The Government Expenditure Efficiency towards the Human Development. Procedia Economics and Finance, 5, pp.615-622.

Sasana, Hadi. 2012. Pengaruh Belanja Pemerintah Daerah dan Pendapatan Perkapita Terhadap Indeks Pembangunan Manusia (Studi Kasus di Kabupaten/Kota Provinsi Jawa Tengah). Media Ekonomi Dan Manajemen, Vol. 25, No. 1, Januari 2012. Hal: 1-12. UNDIP Semarang

Todaro dan Smith. 2003. Pembangunan Ekonomi di Dunia Ketiga. Edisi Kedelapan Jilid 1. Jakarta: Erlangga

Undang-Undang Nomor 23 Tahun 2014 tentang Pemerintah Daerah.
Widarjono, Agus. 2009. Ekonometrika Pengantar dan Aplikasinya. Yogyakarta: Ekonisia

Widodo, Adi, Waridin, Johanna Maria K. 2011. Analisis Pengaruh Pengeluaran Pemerintah di Sektor Pendidikan dan Kesehatan terhadap Pengentasan Kemiskinan Melalui Peningkatan Pembangunan Manusia di Provinsi Jawa Tengah. Jurnal Dinamika Ekonomi Pembangunan, Vol.1, No.1, Juni 2011.Hal 25-42.

Yuliani, T., \& Saragih, N. (2014). Determinan Pembangunan Manusia Di Kabupaten/Kota Provinsi Jawa Tengah. JEJAK: Jurnal Ekonomi Dan Kebijakan, 7(1),60-72. 